\title{
Transdisciplinary service-learning for construction management and quantity surveying students
}

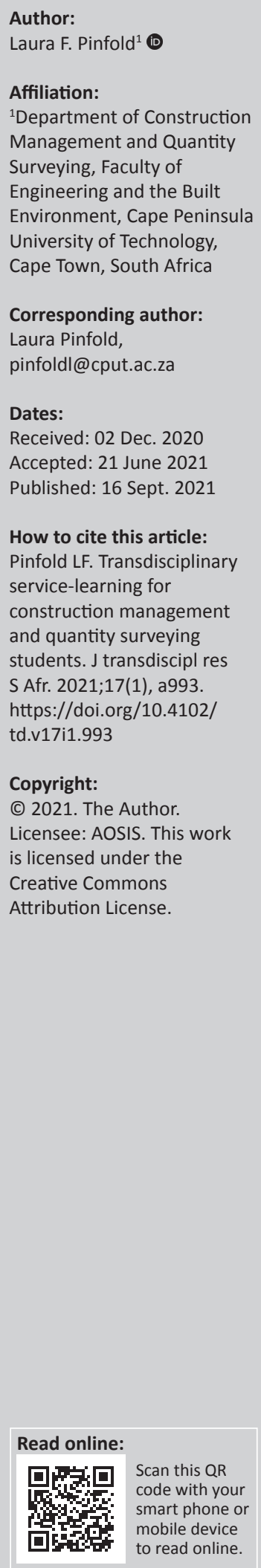

The transformation of higher education in South Africa has seen higher education institutions become more responsive to community matters by providing institutional support for service-learning projects. Despite service-learning being practised in many departments at the Cape Peninsula University of Technology (CPUT), there is a significant difference in the way service-learning is perceived by academics and the way in which it should be supported within the curriculum. This article reflects on a collaborative transdisciplinary servicelearning project at CPUT that included the Department of Construction Management and Quantity Surveying and the Department of Urban and Regional Planning. The aim of the transdisciplinary service-learning project was for students to participate in an asset-mapping exercise in a rural communal settlement in the Bergrivier municipality in the Western Cape province of South Africa. In so doing students from the two departments were gradually inducted into the community. Once inducted, students were able to identify the community's most urgent needs. During community engagement students from each department were paired together. This allowed transdisciplinary learning to happen with the exploration of ideas from the perspectives of both engineering and urban planning students. Students were able to construct meaning beyond their discipline. Cooperation and synergy between the departments allowed mutual, interchangeable, cooperative interaction with community members. Outcomes for the transdisciplinary service-learning project and the required commitment from students are discussed.

Keywords: service-learning; community engagement; asset mapping; transdisciplinary; built environment; construction education; qualitative GIS.

\section{Introduction}

Community engagement within higher education has historically been considered a voluntary service to communities, rather than a core function along with teaching, learning and research. The transformation of higher education in South Africa has seen higher education institutions become more responsive to community matters by providing services and infrastructure for service-learning programmes. ${ }^{1}$ Even though community engagement and service-learning policies are in place at higher education institutions, the implementation of community engagement in the curriculum has been sluggish. Community engagement projects tend to be 'add on' rather than credit-bearing components of the curriculum. ${ }^{2}$ Despite service-learning being practised in many departments at the Cape Peninsula University of Technology (CPUT), there is a significant difference in the way service-learning is perceived by academics and the way in which it should be supported within the curriculum. ${ }^{3}$ This article presents a transdisciplinary service-learning project undertaken by the Department of Construction Management and Quantity Surveying (CM\&QS) at CPUT. Service-learning pedagogy was used to teach first-year diploma students a section of the course in Site Surveying. The servicelearning project included third-year diploma students from the Department of Urban and Regional Planning doing a course in Geographic Information Systems. Using a problembased approach allows students to spend a sufficient amount of time in the community to benefit from the experience. The article begins by briefly outlining service-learning pedagogy in South African universities, followed by a review of the Department of CM\&QS's approach to community engagement. The transdisciplinary service-learning project is then briefly outlined. Empirical evidence of transdisciplinary learning is drawn upon to demonstrate the effectiveness of collaborative service-learning for construction managers and quantity surveyors. The last section is a discussion, which briefly highlights the success of the transdisciplinary service-learning project in the Department of CM\&QS at CPUT followed by a summary of the article. 


\section{Service-learning pedagogy in South African universities}

The three core functions of a university in South Africa are teaching and learning, research and community engagement. ${ }^{4}$ Community engagement is seen as part of the academic workload of staff members. Community engagement informs students about communities through participation where problems are explored and contributions to solutions are made. ${ }^{1}$ Community engagement has the potential to influence students in becoming socially responsive in their careers after graduating. ${ }^{5}$ The notion of Mode 1 and Mode 2 knowledge at universities was highlighted by Gibbons ${ }^{6}$ and his co-authors in their 1994 book, The New Production of Knowledge. Mode 1 knowledge is knowledge validated by logic and measurement within academic communities, whilst Mode 2 knowledge is a local form of knowledge that is socially useful, collaborative and transdisciplinary. ${ }^{7}$ Mode 2 knowledge suggests open, exploratory networks rather than the confined traditional institutional-structured knowledge creation. ${ }^{8}$ The debate regarding these two forms of knowledge at universities continues. Some favour local forms of knowledge over traditional knowledge, whilst others feel that traditional knowledge is being undermined. ${ }^{9}$ The applied sciences tend towards traditional knowledge; however, there has been a surge in community engagement efforts in engineering education. It is true to say that contemporary society demands that universities engage with society in a quest to integrate tacit knowledge with other forms of knowledge in the knowledge economy. Community engagement in South African universities is distinctly concerned with the government agenda to transform and become responsive to the socio-economic issues that face the country. ${ }^{1}$ Auf der Heyde ${ }^{10}$ believed that there needs to be a common concept of community engagement so that it can be assessed together with teaching and learning and research. Slamat ${ }^{11}$ and Nongxa ${ }^{12}$ point out that a common concept of community engagement for all universities is not necessary at this point as community engagement is defined by scholarship through funding and the mission and vision statement of the individual university.

\section{The Cape Peninsula University of Technology as an engaged university}

A university's civic identity and public purpose depend on strategies of engagement. ${ }^{13}$ An engaged university promotes social justice by adopting pedagogies such as service-learning that allow student and academics to work with communities. ${ }^{14}$ The CPUT policy on community engagement ensures that knowledge obtained during service-learning activities is academically accredited and that tacit knowledge is integrated with course content through reflective practice. The CPUT intentions are to integrate institutional aims and goals with community needs responsively and appropriately. At CPUT academics are encouraged to include community engagement in their teaching programmes and to include service-learning pedagogy in course modules.
The service-learning unit at CPUT was established to coordinate community engagement and work-integrated learning across all faculties. This unit is responsible for initiating partnerships and ensuring appropriate student placements. The service-learning unit also coordinates the flow of communication to and from external partners. The level at which students engage with communities on a project is not determined by the service-learning unit but by the respective departments. All logistical arrangements for the implementation of service-learning projects take place within the academic departments involved. The assessment of service-learning projects is carried out along the broad guidelines as set out by the Council for Higher Education. The service-learning unit in collaboration with the CPUT Quality Office monitors and evaluates the role of the servicelearning programme and makes recommendations for improvements.

Internal resource allocation is limited, mainly providing money for transporting students to and from the site. For further funding, project proposals need to be submitted to the service-learning unit. This includes securing external resource and allocation funding available for communities to access resources on campus. Availability of financial resources is crucial for the quality implementation of service-learning. The institution ensures that each academic department is well resourced to carry out service-learning functions.

Despite institutional support for community engagement, service-learning projects do not attract the interest of academic staff. This is because of a lack of incentive. Furthermore, many academics are experts in their disciplines but not in community engagement. A recent study conducted at CPUT found that, despite there being institutional support for community engagement, there is little encouragement at the departmental level. The study found a lack of communication between faculties and departments regarding community engagement projects. This has created a fragmented and uncoordinated approach to service-learning projects. ${ }^{15}$ This is consistent with Nongxa ${ }^{12}$ who identifies poor management as a key concern for ensuring community engagement activities at the departmental level. The difficulty of identifying what is an appropriate community for engagement is another factor that Favish ${ }^{16}$ believes distracts from a departmental enthusiasm in implementing community engagement projects.

\section{Planning and developing a service- learning project for construction managers and quantity surveyors}

Despite CPUT being an engaged university with a multitude of service-learning projects across all faculties, CM\&QS has lagged behind most other disciplines in the use of this pedagogy. The changing face of engineering education requires students to engage with communities. They are required to work in multicultural environments, in multidisciplinary teams and to compete in the global market. 
Implementing a service-learning project has many challenges such as crammed timetables and a demanding curriculum. To encourage more widespread adoption of service-learning in engineering qualifications this article presents a transdisciplinary learning approach to service-learning that enables engineering students to participate in a generic service. The first-year course in Site Surveying contains a project component that is suitable for community engagement. Undergraduate students require more than a compacted technical background in Site Surveying. To do this component of the curriculum students are expected to co-operate with community members of different social and educational backgrounds. These soft skills are important in establishing the growing needs for engineering solutions in community projects. The first challenge was to find a suitable service-learning design.

\section{Design consideration}

Service-learning is seen as an unconventional teaching method. The development of service-learning in the curriculum depends largely on an individual's commitment. It requires a good understanding and knowledge of institutional policy and guidelines that govern servicelearning. Conceptual frameworks need to be put into practice to ensure that this form of teaching is successful and ethically executed. Service-learning demands much more flexibility from lecturers as the course material is not fully controllable because of student learning in the community. Lecturers need to accept that students become a resource of knowledge that needs to be extracted in reflective sessions. Theory and experience become integrated, resulting in the need to ensure that academic standards are strictly upheld. Learning goals must be achieved through well-structured assignments that facilitate student learning from the service experience. The lecturer has the added responsibility of ensuring that students can engage with partners to harvest knowledge during their experience. Classroom teaching and community engagement is distinctly different and requires consistency between the two environments to provide equal opportunities for student learning. Lecturers must therefore disseminate information before engagement, provide support during engagement and then facilitate and guide in reflection after engagement.

The design of a service-learning module has several variables that the lecturer needs to be aware of. The first variable is the formulation of module outcomes. Module outcomes differ depending on the developmental needs of the community. A situational analysis of the community is needed beforehand to ensure that the students can work within the parameters of the community's operation. This requires careful planning to ensure that the academic programme is not compromised in a bid to accommodate the community's needs. Module design can only be determined once a memorandum of understanding has been finalised and signed with the respective partners. The second variable relates to the time spent in the community. The community will determine when engagement can happen and the amount of time available for student activities. This has implications for timetabling of academic work. Provision must be made in the academic timetable to accommodate students on-site so that the required knowledge is gained from the engagement experience. Twenty to forty hours of community engagement is recommended by the Council for Higher Education resource manual. ${ }^{17}$ The third variable relates to the challenges of placing students in the community. These include community readiness to host students, the student's readiness to engage with the community, weather conditions and logistical arrangements such as transport and safety. Furthermore, care must be taken not to demoralise or frustrate students in their placement within the community.

\section{Selecting a community engagement partner}

An effective method of finding a community partner is the 'shopfront' model. The 'shopfront' model is a universitywide programme where each faculty advertises themselves in a bid to attract community engagement. This model acts as a gateway for communities to access the university's knowledge and resources in a bottom-up approach that ensures community-led rather than institutional-dominated projects. Communities can approach all faculties rather than just one proactive faculty or department. This model is collaborative and multidisciplinary where community groups, academics and students work together in all facets of a community engagement project, within an innovative and supportive environment. Widespread participation is an important part of ensuring that the community engagement project is sustainable. ${ }^{18}$ The project outcomes become multidisciplinary, shaped by the community and institution together rather than by the community and individual faculties and departments. This multidisciplinary approach can involve many subjects, supervised by academics and spanning over several semesters, or it can involve small projects requiring only a few students. The strength of this model is in the central control and coordination of projects rather than a fragmented individualistic and uncoordinated approach to projects at the departmental level. This multidisciplinary approach ensures a uniform way of dealing with community groups. ${ }^{19}$ Furthermore, a community's willingness and agency to form a partnership with the university demonstrates that the community has the vitality, which is key to a successful partnership. ${ }^{20}$

Another model that has been successful for postgraduate students is the 'science shop' model, developed in Europe in the 1970s. This model encourages community-based organisations, local and central government and labour unions to submit community engagement proposals to the central research office. The central research office serves all faculties and matches the proposal with appropriate faculty or department. The project output is research-based and is presented in the form of a thesis at honours or master's level. This model ensures that the designated student is matched to the particular community's needs and therefore ensures a productive partnership. ${ }^{21}$ 
The service-learning unit at CPUT encourages a transdisciplinary approach to service-learning. The Department of Urban and Regional Planning in the Faculty of Informatics and Design decided to establish a servicelearning project for their course in geographic information system (GIS). The 'shop front' method for attracting a potential community partner was used. A rural community within the jurisdiction of the Bergrivier local municipality in the West Coast region of the Western Cape province approached the department to assist them with spatial planning guidelines for their community. The community is located on a farm with no cadastral information or services. It was decided that the first service to the community would be a GIS to document, map and benchmark social assets within the community. The GIS is used to capture the quantity and quality of community assets for future development work in the community. ${ }^{22}$ The emphasis was on infrastructure availability for different types of asset and activities. Furthermore, the geographic information gathered would allow the community to lobby the local government for much-needed assistance and services. The service-learning project is ongoing with students adding and improving the GIS each year. As a result of the transdisciplinary nature of community mapping, it was agreed that first-year CM\&QS students would join the planning students. Asset mapping is a valid component of the CM\&QS course and specifically the Site Surveying module. The contribution engineering students offer in building a GIS is the planning and operational aspect of infrastructure, whilst the planning students focus on the future development and overall use of infrastructure.

\section{Organising the project}

Upfront organisation of logistics was critical to the success of the transdisciplinary service-learning project. The inclusion of the engineering students was negotiated with community members involved. The timetabling of student fieldtrips was carefully planned to suit both departments and the community participants. Only 24 students were allowed in the community each week. The number of students involved varied year by year (engineering students - 130 in 2014, 220 in 2015 and 20 in 2018). Approximately 50 Urban and Regional Planning students participated each year. Field trips were arranged from July to November. Students from each department were grouped and assigned to a neighbourhood in the community. Each group was accompanied by a community member. Transport to and from the community was arranged by the service-learning unit. Students were supervised by a lecturer from one of the departments on each fieldtrip. The service-learning unit provided student induction training regarding servicelearning protocols.

\section{Analysis and reflection}

The pedagogy of service-learning is grounded in reflection, which enables learning to occur. Feedback in the form of reflection sessions was critical to assess the outcomes of the experience. Reflective sessions were conducted before, during and after site visits. The reflection beforehand highlighted the student's anticipation and expectations. Strict procedural skills onsite allowed students to gain selfconfidence, self-esteem and personal growth. Students were able to assess each other's proficiency in acting independently and making decisions on their own as well as their ability to work together within their multidisciplinary groups. Importantly students could contextualise their experience with the theory learnt in the classroom. Students were encouraged to ask questions and derive new meaning to what they had learnt. The lecturer's responsibility was to develop a meaningful connection between the experience and course content as well as to encourage students to explore issues more deeply. Reflection afterwards provided students with an opportunity to consolidate their learning experience. The reflection activities took on various forms. These included presentations to classmates, student journal submission and a qualitative questionnaire about their experience. Students were able to reveal their expectations before, experiences during and perception after the engagement.

\section{Assessing student performance}

Students were assessed on their agency and academic outcomes rather than the service itself. Assessment measures included traditional assessment tools and reflection presentations, student journals, logs and a final portfolio, which were all peer-evaluated. The community deliverable was a GIS map that was added to and improved upon year by year. The community partners had an opportunity to evaluate student performance through a feedback mechanism set up by the service-learning unit. This included visits to partners and the community.

\section{Ethical considerations}

The CPUT policy and procedures for service-learning directs all service-learning projects. Proposed servicelearning projects are initiated at the departmental level, then submitted to the faculty for approval and finally registered as a service-learning project with the service-learning unit. All sites for service-learning projects are visited and approved by CPUT and service partners before the commencement of the placement of students and academics to enhance the chance of a favourable learning environment. Ethical approval for service-learning projects is not required from the Faculty Research Ethics Committee unless there is a research component attached to the service-learning project. The service-learning project discussed in this article was solely a teaching and learning experience. Consent amongst stakeholders was obtained in the form of a memorandum of understanding. The memorandum of understanding outlines the purpose of the partnership, nature of the partnership, responsibilities of all parties in the partnership and dispute resolution. Guiding principles set out include: the benefit to the community; commitment to a community-led process; work produced should further the 
aims and identified priorities of the community; and once the students leave, the community must be left with something the community can follow up on that leads to implementation.

\section{The transdisciplinary service-learning project}

The transdisciplinary service-learning project discussed is a participatory asset-mapping exercise. Participatory asset mapping is a process of documenting the existing resources in a community. Community members collectively identify their assets and represent them on a map. The map is then used for future development work in the community. University departments from different disciplines can take part in this task. The mapping exercise serves as a vehicle to gradually induct students into communities and allow partnership building. Once this has been achieved the task of identifying the community's most urgent needs can be realised. The Department of CM\&QS participated in the participatory asset-mapping exercise in the hope that students gain an insider perspective of the community. The transdisciplinary service-learning project steering committee was made up of specific community interest groups who wanted to participate in the service-learning activities. These interest groups defined their outcomes to ensure a bottom-up approach to the development of the community. The academics at CPUT were responsible for ensuring that a clear connection existed between the community's defined outcomes and the relevant academic module outcomes. This mixing of outcomes strengthened the prospect of reciprocity of knowledge during the project.

Service-learning projects generally take on three different forms: discipline-based, problem-based and capstonebased. ${ }^{17}$ Discipline-based service-learning projects require that students have a continuous presence in the community throughout the project. The capstone approach involves postgraduate students. Postgraduate students are selected because they can conduct themselves more professionally and require less supervision; they also offer more knowledge, skills and value to the project and are therefore more effective at finding a solution. Furthermore, postgraduate students can gather personal experience that can be useful to them in practice. Problem-based service-learning requires that students work with community residents to understand a specific problem. The transdisciplinary service-learning project is problem-based requiring students to gather and disseminate information during site visits.

The transdisciplinary service-learning project achieved certain cross-field outcomes. These included skills such as critical and creative thinking, being able to work in groups and communicate across languages. Students were required to work with people at varying academic levels, with different home languages and with expectations that sometimes exceeded the brief of the project. The problems confronting students were not simple and were in some instances unsolvable. This problem-based exercise required students to think critically, be strategic and communicate their ideas in creative ways. Students needed to be tolerant and sensitive to the culture of the community and make sure they did not offend anyone. Furthermore, students had to act in a socially responsible way when confronted with the problems facing the community. At the same time, students had to relate their experiences to the outcomes of their academic module and ensure that the collective objectives of the project were achieved.

\section{Empirical evidence of transdisciplinary service-learning}

The aim of the service-learning project was for students to put forward innovative ideas that would empower the community to lobby local government for better services and support. Student groups were multidisciplinary and were required to collectively come up with ideas. This created transdisciplinary learning that crossed disciplinary boundaries incorporating ideas, feelings and facts provided by the community. Transdisciplinary learning allowed the exploration of ideas from the perspectives of both engineering and urban planning students. New knowledge was constructed, giving the students a deeper understanding of development issues within the community. The lecturer's rapport with students allowed shared ideas that resulted in meaningful and enduring understanding for students. The project exposed students to real-life scenarios with openended problems, sometimes with no obvious solution. Transdisciplinary learning provides a wider understanding of the muddled problems engineers are faced within their professional lives. Engineering, urban planning and environmental problems are all interconnected in complex ways. During reflective sessions many students contributed outside their disciplinary backgrounds, which is a clear indication that transdisciplinary learning happened, developing knowledge beyond the student's disciplinary awareness.

The outcomes required from the transdisciplinary servicelearning project:

- Understand others through observation and participation.

- Become adequately versed in disciplines and fields other than one's own.

- Create a shared conceptual framework for community engagement.

- Integrate dissimilar concepts through collaboration.

- Address complex problems at the intersection of one's discipline.

- Engage in cross-disciplinary knowledge building to understand and address community matters.

The equitable contribution required of students:

- Participate continuously.

- Contribute to problem-solving.

- Adapt to various communication types and skills.

- Relate the community engagement experience to theoretical work taught in the classroom. 


\section{Discussion}

Education at university is about learning new values and ways of understanding the world, a world that is becoming increasingly complex, more unequal and diverse. Servicelearning is embedded within academic classes and requires students to learn through participating in community engagement activities. It is intended to help students achieve their academic goals and to develop a sense of citizenship. There are two forms of service-learning, charitable and social change. ${ }^{23}$ The transdisciplinary servicelearning project described in this article is transformative rather than philanthropic where the development of agency and social capital encourages community development and thus social change. The reason for actively choosing social change over charity is that charity creates certain expectations that cannot always be achieved. The community in which the service-learning project resides has limited services. As a result, residents see community development through a negative lens. Community asset mapping is a strength-based approach to encourage community development by empowering residents to recognise their strengths and capacities.

A simple definition of transdisciplinary is unitary knowledge by joining, combining and transcending skills of disciplines in understanding a concept, issue or problem. ${ }^{24}$ Some argue that transdisciplinary should exclude a methodology altogether to facilitate joint problem solving. ${ }^{6}$ Transdisciplinary education is creating new knowledge of real-life experiences from the perspectives of multiple disciplines. Transdisciplinary research is creating new theory by integrating the approaches of multiple disciplines. Transdisciplinary pedagogy is a way of teaching the curriculum through collaboration and interaction. It is the understanding and development of collective and distributed knowledge. ${ }^{25}$ The collaboration consists of multiple opportunities with people who have different experiences and knowledge. The Site Surveying course in which the service-learning project resides is aimed at equipping students with setting out skills on a construction site. Service-learning and transdisciplinary pedagogy in Site Surveying were introduced to develop the students' relationship with the communities they serve. The reason for choosing Site Surveying as a host for the service-learning project was the connection between setting out (the location of points for columns and other necessary structural parts) and coordinating as-built features (such as sewerage, power lines and buildings). Transdisciplinary pedagogy facilitates community engagement where students from multiple disciplines and the community collaborate with a different understanding of the same complex issues. Students develop their way of thinking by seeing things from multiple perspectives. This environment of learning is intended to provide a more engaged and motivated student who considers the impact on specific groups of people, the environment and society more broadly.
The academic relevance of the service-learning project is the sharing of knowledge where both student and community experiences contribute to knowledge production. This is very unlike traditional models of learning in the university context where theory is taught in the classroom and practicals are carried out in the field. Experiential activities such as site-based experience in construction education are important for undergraduates to understand the necessary issues associated with construction. The idea behind experiential learning is to experience how theory can be seen in practice. Experiential service-learning provides a way for students to learn from the experience they acquire working with community members. It is argued in this article that engineers tend to see service-learning too objectively. The service described in the service-learning project and discussed in this article is creating shared values, agency and social capital whilst the learning is understanding the complex and often confusing nature of communities. This enables an engineer to better plan and design his or her work. Students were asked to consider what influence their discipline has on specific groups of people through interactions with them. This was performed through community-led asset mapping as described in this article. Asset mapping is information about the strengths of the community. The aim is to reach a point of appreciative knowledge together, recognising local expertise with a sincere willingness to learn from each other.

A factor that complicates setting up a service-learning project is accommodating field trips in the department timetable. Clashes in the timetable had to be negotiated with other lectures. The solution was to reserve 1 day a week for practicals and community field trips. Students were put into groups of 13. Each group was given a schedule of practical dates. The remaining time was available for community field trips. At least two community field trips were required in the semester, which amounted to approximately $18 \mathrm{~h}$. In the last week of the semester, all students were bussed into the community for a 1-day final presentation and reflection. A community field trip involves leaving the university at 8 o'clock in the morning and returning at 5:30 in the evening. On arrival in the community, students were divided into groups consisting of a mix of Urban and Regional Planning students and CM\&QS students. Each group was allocated an area in one of the neighbourhoods and were assisted by community residents. Together, by using mobile GIS equipment, they gathered geographic information of community assets and associated attribute data. Although academically, as well as practically, the gap in experience between first-year and third-year students is broad, the intention is to encourage student agency in a real-life situation. This should not be dependent on academic skills or experience. Community members contribute to shared knowledge through their understanding of the social dimension of their society. The perspectives of students from different disciplines necessitate critical thinking and an interpersonal understanding of community needs. 


\section{Conclusion}

The transdisciplinary service-learning project provided students with a transdisciplinary learning experience by using the service-learning pedagogy. During the project, students were able to apply academic theory taught in the classroom within a community setting. Student's knowledge, skills and educational thinking were stimulated through 'knowledge by acquaintance', inspiring a higher order of thinking through real-life experience. The pedagogy of service-learning is grounded in reflection, which enables learning to occur. The connection between theory and practice is achieved through reflection sessions prepared in the classroom before, during and after engagement. Reflection sessions are critical in assessing the outcomes of the experience. Students were able to discuss the effectiveness of their role as agents in the community. Importantly students needed to contextualise the experience with the theory learnt in the classroom. The ultimate goal was to gain knowledge of the module content and understand it in the context of a community setting.

Asset mapping is an innovative way of visualising the needs and potential of a community. Once it is performed, development can be based on the strengths and resources of the community. Members from all sectors of the community should participate. The mapping exercise can be simple, by using multiple tools, methods and sources. This ensures a wide range of participation. Departments across faculties in the university can partake regardless of differing disciplines. The purpose of asset mapping is (1) to allow students to experience community engagement and (2) provide the community with a GIS map that can be used to lobby local government for much-needed services and support. When departments and community work together a transdisciplinary learning experience is created where disciplinary boundaries are dissolved and blended with community knowledge. The hope is that this transdisciplinary service-learning project will encourage academics who normally shy away from service-learning to reconsider.

\section{Acknowledgements Competing interests}

The author declares that they have no financial or personal relationships that may have inappropriately influenced them in writing this article.

\section{Author's contributions}

L.F.P. is the sole author of this research article.

\section{Funding information}

This research received no specific grant from any funding agency in the public, commercial or not-for-profit sectors.

\section{Data availability}

Data sharing is not applicable to this article as no new data were created or analysed in this study.

\section{Disclaimer}

The views and opinions expressed in this article are those of the author and do not necessarily reflect the official policy or position of any affiliated agency of the authors.

\section{References}

1. Thomson A, Smith-Tolken A, Naidoo T, Bringle R. Service learning and community engagement: A comparison of three national contexts. Int Soc Third-Sector Res John's Hopkins Univ. 2011;22(2):214-237. https://doi.org/10.1007/s11266-010-9133-9

2. Lazarus J, Erasmus M, Hendricks D, Nduna J, Slamat J. Embedding community engagement in South African higher education. Educ Citizensh Soc Justice. 2008;3(1):57-83. https://doi.org/10.1177/1746197907086719

3. Mokhele $M$, Pinfold $N$. Foundation for transdisciplinary education at Cape Peninsula University of Technology. J Transdiscip Res S Afr. 2020;16(1):1-9. https://doi.org/10.4102/td.v16i1.749

4. Hall M. Community engagement in South African higher education. Community engagement in South African higher education. Kagisano no. 6. Auckland Park: Council on Higher Education; 2010; p. 1-52.

5. Bringle R, Steinberg K. Educating for informed community nvolvement. Am J Community Psychol. 2010;46(3-4):428-441. https://doi.org/10.1007/s10464010-9340-y

6. Gibbons M, Limoges C, Nowotny H, Schwartzman S, Scott P, Trow M. The new production of knowledge: The dynamics of science and research in contemporary societies. Contemp Sociol. 1994;24(6):751-752. https://doi.org/10.2307/2076669

7. Gibbons M. Engagement as a core value in a Mode 2 society. Paper Presented at: The Community Engagement in Higher Education Conference; 2006 Sept 3-5; Cape Town. p. 1-43.

8. Hall M. Community engagement in South African higher education. Paper Presented at the CHE Symposium on Community Engagement; 2009 Mar 19; Pretoria. p. 1-52.

9. Muller J. Reclaiming knowledge: Social theory, curriculum and education policy. London: Routledge; 2000

10. Auf Der Heyde T. Towards a management framework for community engagement and public scholarship. 2005. Unpublished paper.

11. Slamat J. Community engagement as scholarship: A response to Hall. Community Engagement - Kagisano no. 6. Auckland Park: Council on Higher Education; 2010; p. 104-114.

12. Nongxa L. An (engaged) response to Hall's paper: Community engagement in South African higher education. Community Engagement - Kagisano no. 6. Auckland Park: Council on Higher Education; 2010; p. 53-67.

13. Hollender E, Saltmarsh J, Zlotkowski E. Indicators of engagement. In: Simon L, Kenny M, Brabeck K, Lerner R, editors. Learning to serve: Promoting civil society through service-learning. Norwell, MA: Kluwer; 2002; p. 31-49.

14. Appe S, Rubaii N, Líppez-De Castro S, Capobianco S. The concept and context of the engaged university in the global south: Lessons from Latin America to guide a research agenda. J High Educ Outreach Engagem. 2017;21(2):7-36.

15. Nchu F, Pinfold N, Jackson D, Tyalana, N. Paper presented at Community Engagement and Service-Learning. Proceeding at the Stellenbosch University short course, Community Engagement and Service-Learning; 2013 May 15-16; Bellville: Stellenbosch University. p. 1-15.

16. Favish J. Towards developing a common discourse and a policy framework for social responsiveness. Community Engagement - Kagisano no. 6. Auckland Park: Council on Higher Education; 2010; p. 89-103.

17. Council on Higher Education. Higher Education Quality Committee. Service-learning in the curriculum. A Resource for Higher Education Institutions. 2006, The Council on Higher Education.

18. Bridger J, Luloff A. Building the sustainable community: Is social capital the answer? Socio Inq. 2001;71(4):458-472. https://doi.org/10.1111/j.1475-682X.2001.tb01127.x

19. Smith-Tolken A. Perspectives on the Shopfront Model of the University of Technology, Sydney (Australia). Stellenbosch University Community Interaction. Symposium Report: Conceptualising Community Engagement Interaction for a 21st Century University. 2012 Sept 6. Stellenbosch University.

20. Dale A, Newman L. Community vitality: The role of community-level resilience adaptation and innovation in sustainable development. Sustainability. 2010;2(1):215-231. https://doi.org/10.3390/su2010215

21. Schmidt B. Reflection on the University of Cape Town (UCT) knowledge co-op: Community influencing the research agenda. Stellenbosch University Community Interaction. Symposium Report. Conceptualising Community Engagement Interaction for a 21st Century University. 2012 Sept 6. Stellenbosch University.

22. Archer D, Luansang C, Boonmahathanakorn S. Facilitating community mapping and planning for citywide upgrading: The role of community architects Environment \& Urbanization. Int Inst Environ Dev. 2012:24(1):115-129. https:// doi.org/10.1177/0956247812437132

23. Peterson N, Osman R. An introduction to service learning in South Africa. In Osman R, Peterson N, editors. Service learning in South Africa. Cape Town: Oxford University Press, 2017; p. 2-30.

24. Nicolescu B. 'Methodology of transdisciplinarity - Levels of reality, logic of the include middle and complexity'. Transdiscip J Eng Sci. 2010;1(1):19-38. https:// doi.org/10.22545/2010/0009

25. Stokols D, Hall KL, Moser RP, Feng A, Misra S, Taylor BK. Cross-disciplinary team science initiatives: Research, training, and translation. In: Frodeman R, Klein JT, Mitcham C, Holbrook JB, editors. The Oxford handbook of interdisciplinarity. New York, NY: Oxford University Press; 2010; p. 471-493. 